\title{
KEUNGGULAN KOMPETITIF PRODUK TEPUNG KELAPA PADA PT. PUTRA KARANGETANG MINAHASA SELATAN
}

\author{
Amelia Prisilia Sarah Tombeng \\ Leonardus R. Rengkung \\ Nordy F. L. Waney
}

\begin{abstract}
The purpose of this study to determine the competitive advantage of coconut flour products at PT. Putra of Karangetang as measured by Low Cost Strategy, Product Differentiation and Focus Strategy. Research conducted at PT. Putra Karangetang located in Popontolen Village, Tumpaan Sub-District, South Minahasa Regency, in March 2017 until May 2017. The data used are primary data through direct interview and filling questionnaire with sampling using simple random sampling method as much as 30 respondents who bought the product in PT. Putra of Karangetang, South Minahasa. The data is measured using Likert scale. The results showed the process of measuring the competitive advantage of coconut flour products at PT. Putra Karangetang South Minahasa total data retrieval 1517 which shows the index rate measuring consumer satisfaction of $72.23 \%$ and quite satisfied. This indicates that the company in PT. Putra Karangetang Minahasa Selatan aware about the benefits of coconut flour products in PT. Putra of Karangetang seen from low cost strategy, product difference strategy, focus strategy.
\end{abstract}

Keywords: competitive advantage, coconut flour, PT. Putra Karangetang, Popontolen Village, Tumpaan District, South Minahasa Regency.

\begin{abstract}
ABSTRAK
Tujuan penelitian ini untuk mengetahui keunggulan kompetitif produk tepung kelapa pada PT. Putra Karangetang yang diukur dengan Strategi Biaya Rendah, Pembedaan Produk dan Strategi Fokus. Penelitian dilakukan di PT. Putra Karangetang yang terletak di Desa Popontolen, Kecamatan Tumpaan, Kabupaten Minahasa Selatan, pada bulan Maret sampai bulan Mei 2017. Data yang digunakan adalah data primer melalui wawancara langsung dan pengisian kuesioner dengan pengambilan sampel menggunakan metode simple random sampling sebanyak 30 responden yang membeli produk di PT. Putra Karangetang Minahasa Selatan. Data diukur menggunakan skala likert. Hasil penelitian menujukkan proses pengukuran keunggulan kompetitif produk tepung kelapa pada PT. Putra Karangetang Minahasa Selatan total skor pengambilan data 1517 yang menujukkan angka indeks pengukuran kepuasan konsumen sebesar 72,23\% dan tergolong puas. Hal ini menujukkan bahwa perusahaan di PT. Putra Karangetang Minahasa Selatan sadar mengenai keunggulan dari produk tepung kelapa di PT. Putra Karangetang yang dilihat dari strategi biaya rendah, strategi perbedaan produk, strategi fokus.
\end{abstract}

Kata kunci: keunggulan kompetitif, tepung kelapa, PT. Putra Karangetang, Desa Popontolen, Kecamatan Tumpaan, Kabupaten Minahasa Selatan.

\section{PENDAHULUAN}

Organisasi memiliki tujuan memelihara kesinambungan bisnis jangka panjang dapat terjamin bilamana perusahaan dihadapkan pada ketidakpastian lingkungan ketika berupaya untuk mencapai tujuan tersebut sehubungan dengan peluang dan ancaman yang ada di lingkungan. Upaya untuk mencapai tujuan maka perusahaan harus menganalisis lingkungan, menganalisis internal, mengidentifikasi peluang sehingga dapat memiliki arah yang akan dituju serta dapat mencapai tujuan perusahaan. Organisasi harus 
memiliki strategi dalam mencapai tujuannya untuk memperoleh keunggulan kompetitif diantaranya, membentuk suatu positioning yang tepat, mempertahankan pelanggan yang tepat, mendapatkan pangsa pasar yang baru, maksimalkan penjualan, menciptakan kinerja bisnis yang efektif (Kotler dalam Amstrong, 2001).

Perusahaan harus mampu mengintegrasi strategi dan berbagai sumberdaya yang dimiliki dalam rangka penciptaan untuk menjadi lebih baik dan unggul dengan memperbaiki proses operasi yang selama ini diterapkan di perusahaan. Keunggulan kompetitif merujuk pada kemampuan sebuah perusahaan untuk memformulasikan strategi yang menempatkannya pada suatu posisi yang menguntungkan berkaitan dengan perusahaan lainnya. Keunggulan kompetitif muncul bila pelanggan merasa bahwa mereka menerima nilai lebih dan transaksi yang dilakukan dengan sebuah perusahaan pesaingnya (Setiawan, 2006).

Keunggulan kompetitif merupakan suatu keunggulan yang dapat membearikan nilai tambah bagi perusahaan dan hanya sedikit perusahaan yang dapat melakukan tindakan serupa. Kinerja Perusahaan sangat mempengaruhi bahkan tergantung pada kualitas dan kemampuan kompetitif yang dimilikinya. Sumberdaya manusia merupakan salah satu penggerak utama bagi setiap perusahaan dalam operasi perusahaan sehingga dalam upaya pengembangan sumberdaya manusia tersebut merupakan strategi utama untuk menegakkan kompetisi global (Gibson, 2010).

Porter (1996), menyatakan bahwa fungsi utama manajemen berkaitan dengan strategi, yakni menetapkan dan mengkomunikasikan posisi unik dari perusahaan, membuat trade off, dan berusaha menciptakan kesesuaian dalam berbagai aktivitas. Beberapa menekankan hubungan strategi dan tujuan perusahaan, sedangkan yang lain berfokus pada penyesuaian peluang di lingkungan dengan kekuatan perusahaan, sementara yang lain menekankan pada karakter subyektf dan psikologis dari strategi.
Tepung kelapa merupakan salah satu produk ekspor unggulan di Sulawesi Utara, pasarannya telah memenuhi permintaan di lima Negara masing-masing Belgia, Austria, Brasil, Belanda dan Jerman. PT. Putra Karangetang adalah salah satu perusahaan tepung kelapa yang terletak di Desa Popontolen Kecamatan Tumpaan Kabupaten Minahasa Selatan yang beroperasi sejak tahun 2001. Untuk menjaga eksistensinya perusahaan harus memiliki strategi dalam menghadapi tantangan persaingan yang ada. Perusahaan mampu bersaing dan memiliki tujuan kinerja baik diwujudkan dengan mengimplementasikan dari satu tujuan penting dalam mendirikan perusahaan untuk meningkatkan kesejahteraan semua elemen dari perusahaan termasuk didalamnya karyawan dari perusahaan tersebut (Brigham dan Hauston, 2001). Upaya mencapai keunggulan kompetitif perusahaan harus melakukan pendekatan tentang bagaimana mengaktifkan potensi sumberdaya yang tersedia. Perusahaan dengan produktivitas tertinggi dalam suatu industri biasanya memiliki biaya produksi yang rendah karena keunggulan kompetitif.

Perusahaan selain memiliki keunggulan kompetitif bertujuan memenangkan persaingan di dalam lingkungan bisnis, perusahaan harus menggunakan keunggulan kompetitif sebagai salah satu kinerja yang di inginkan oleh perusahaan, sesungguhnya perusahaan merupakan hasil atau output yang dihasilkan, perusahaan diukur dan dibandingkan dari hasil atau output yang diharapkan Jahanshahi (2012). Keunggulan bersaing menurut Porter (1986), keumampuan perusahaan dalam meraih keuntungan, Perusahaan harus mampu melihat dari "Cost Leadership" yaitu biaya rendah menekankan pada upaya memproduksi produk standar dengan biaya per unit yang sangat rendah, untuk dapat menjalankan strategi biaya rendah, sebuah perusahaan harus mampu memenuhi syarat di dua bidang yaitu: sumber daya (resources) dan organisasi. Differensiasi strategi ini mendorong perusahaan untuk sanggup menemukan keunikan tersendiri dalam pasar yang jadi sasarannya, differensiasi tidak memberikan jaminan terhadap keunggulan kompetitif, terutama jika produk-produk standar 
telah relatif memenuhi kebutuhan konsumen atau jika kompetitor dapat melakukuan peniruan dengan cepat. Fokus digunakan untuk membangun keunggulan bersaing dalam suatu segmen pasar yang lebih sempit, strategi ini biasa digunakan dan memahami struktur pasar dan mampu memilih strategi pemasaran yang efektif.

\section{Perumusan Masalah}

Berdasarkan latar belakang yang telah dikemukakan yang menjadi masalah dalam penelitian ini adalah bagaimana keunggulan kompetitif dari produk tepung kelapa pada PT. Putra Karangetang?

\section{Tujuan Penelitian}

Tujuan penelitian ini untuk mengetahui keunggulan kompetitif produk tepung kelapa pada PT. Putra Karangetang yang diukur dengan Strategi Biaya Rendah, Pembedaan Produk dan Strategi Fokus.

\section{Manfaat Penelitian}

Penelitian ini diharapkan bermanfaat untuk membantu perusahaan dalam meningkatkan keunggulan kompetitif pada produk tepung kelapa dan bagi siapa saja yang berminat meneliti tentang keunggulan kompetitif.

\section{METODOLOGI PENELITIAN}

\section{Tempat dan Waktu Penelitian}

Penelitian dilakukan di PT. Putra Karangetang yang terletak di Desa Popontolen Kecamatan Tumpaan Kabupaten Minahasa Selatan. Penelitian berlangsung selama 4 bulan dari persiapan sampai penyusunan laporan, yaitu pada bulan Maret sampai bulan Mei 2017.

\section{Metode Penelitian}

Data yang digunakan dalam penelitian ini adalah data primer yang bersifat kualitatif, yang berkaitan dengan pengukuran Keunggulan Kompetitif, yaitu: Biaya Rendah, Perbedaan Produk dan Fokus. Data tentang Biaya Rendah ditanyakan pada pelanggan dan data tentang perbedaan produk dan Fokus ditanyakan pada pimpinan dan karyawan.
Pengumpulan data menggunakan daftar pertanyaan yang ditanyakan pada pimpinan dan karyawan perusahaan serta konsumen. Data kualitatif tersebut dikuantifikasi dengan menggunakan Skala Likert dengan jenjang 1 sampai 5 yaitu:

$$
\begin{aligned}
& 1=\text { Sangat Tidak Setuju } \\
& 2=\text { Tidak Setuju } \\
& 3=\text { Netral } \\
& 4=\text { Setuju } \\
& 5=\text { Sangat Setuju }
\end{aligned}
$$

\section{Metode Pengambilan Sampel}

Populasi dalam penelitian ini adalah pimpinan dan karyawan PT. Putra Karangetang Minahasa Selatan dan diambil sampel secara sengaja (purposive sampling) sebanyak 30 responden.

\section{Konsepsi Pengukuran Variabel}

A. Karakteristik Responden mencakup : umur, jenis kelamin, tingkat pendidikan, jabatan dan jenis pekerjaan.

B. Variabel Keunggulan Kompetitif yaitu:

1. Strategi Biaya Rendah

a. Harga jual: harga jual produk sama atau lebih rendah dari pesaing.

b. Harga bahan baku: perusahaan berupaya mendapatkan bahan baku yang rendah/murah.

c. Jangkauan pasar produk yang besar dan luas.

d. Sumberdaya: Pemanfaatan sumber daya optimal.

e. Sumber pembiayaan: Kemampuan mendapatkan sumber pembiayaan dengan tingkat bunga yang rendah.

f. Pengendalian persediaan: Kemampuan mengendalikan persediaan yang ketat

2. Strategi Pembedaan Produk

a. Kelebihan dan kekurangan produk: mempelajari secara kontinu kelebihan dan kekurangan produk-produk pesaing.

b. Perbedaan produk: produk yang dihasilkan berbeda dengan pesaing.

c. Harga jual produk: harga produk yang terbaru dan bersaing.

d. Pemanfaatan teknologi: penggunaan teknologi yang baru. 
e. Research and Development: Memiliki pusat Research and Development.

3. Strategi Fokus
a. Fokus pada pasar/konsumen: Kemampuan mempertahankan pasar/konsumen yang sudah ada.
b. Penentuan harga pasar: memiliki konsep penentuan harga pasar (permintaan).

c. Kualitas produk: Kemampuan mempertahankan kualitas produk yang dihasilkan.

\section{Metode Analisis Data}

Analisis data dalam penelitian ini adalah deskriptif yaitu dengan menjelaskan semua variabel pengukuran yang berkaitan dengan Keunggulan Kompetitif dan elemen-elemennya yang diukur dengan menggunakan Skala Likert yaitu 1 (Sangat Tidak Setuju), 2 (Tidak Setuju), 3 (Netral), 4 (Setuju) dan 5 (Sangat Setuju).

Analisis dilakukan dengan menghitung jumlah skor masing-masing skala (kriteria) yaitu dengan perkalian antara capaian skor dengan jumlah responden yaitu :

Jumlah skor tiap kriteria = capaian skor $\mathrm{X}$ jumlah responden untuk :

$$
\begin{aligned}
& \mathrm{S} 1=1 \times 30=30 \\
& \mathrm{~S} 2=2 \times 30=60 \\
& \mathrm{~S} 3=3 \times 30=90 \\
& \mathrm{~S} 4=4 \times 30=120 \\
& \mathrm{~S} 5=5 \times 30=150
\end{aligned}
$$

Jumlah skor ideal untuk setiap pertanyaan $($ skor tertinggi $)=150$

Jumlah skor terendah $=30$

dengan interpretasi nilai :

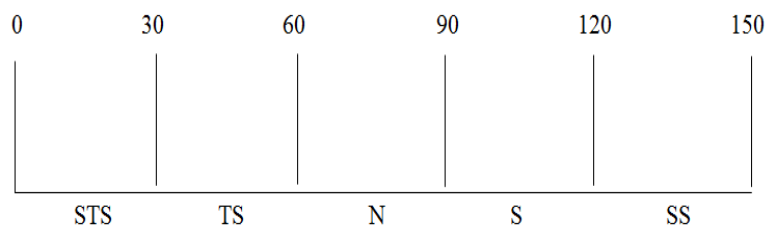

Cara perhitungan skor keseluruhan untuk mengetahui unsur-unsur Keunggulan Kompetitif.

Jumlah skor seluruh kriteria = Capaian jumlah skor X Jumlah Responden X Instrumen pertanyaan

Untuk pertanyaan terhadap Pimpinan dan Karyawan
$\mathrm{S} 1=1 \times 30 \times 14=420$

$\mathrm{S} 2=2 \times 30 \times 14=840$

$\mathrm{S} 3=3 \times 30 \times 14=1260$

$\mathrm{S} 4=4 \times 30 \times 14=1680$

$\mathrm{S} 5=5 \times 30 \times 14=2100$

Jumlah skor ideal untuk keseluruhan pernyataan 2100 (tertinggi)

Jumlah skor terendah 420

Dengan interpretasi nilai :

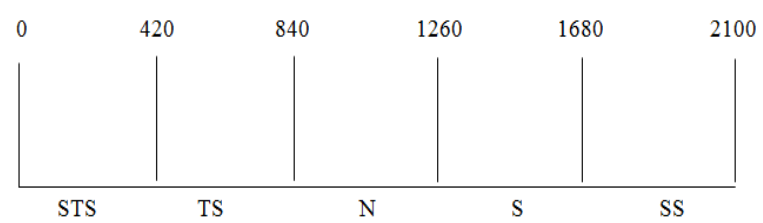

Analisis data yang digunakan merupakan analisis deskriptif yang dianalisis dengan menggunakan skala pengukuran Skala Likert sebagai berikut :

$$
\text { Keunggulan Kompetitif } \frac{=\text { Jumlah Skor Hasil Pengumpulan DataX } 100 \%}{\text { Jumlah skor Ideal (tertinggi) }}
$$

Dengan interpretasi nilai :

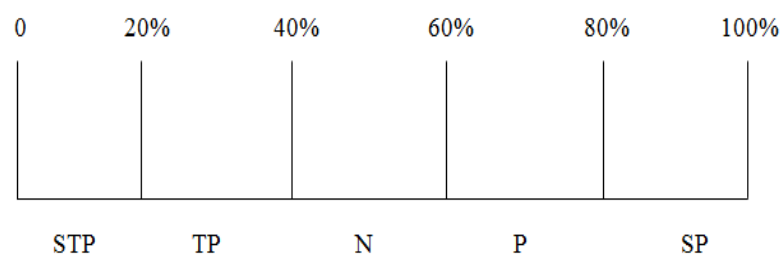

Keterangan kriteria interpretasi skor unsurunsur Keunggulan Kompetitif :

Angka $0 \%-20 \%=$ Sangat Tidak Puas

Angka 20\% - 40\% = Tidak Puas

Angka $40 \%-60 \%=$ Netral

Angka $60 \%-80 \%=$ Puas

Angka $80 \%-100 \%=$ Sangat Puas

\section{HASIL DAN PEMBAHASAN}

\section{Deskripsi PT. Putra Karangetan Minahasa Selatan}

PT. Putra Karangetang merupakan tempat memproduksi bahan-bahan alami yaitu produk minyak kelapa dan produk tepung kelapa. PT. Putra Karangetang berdiri sejak 04 April Tahun 2001 dan telah memiliki banyak pengalaman dalam memasok tepung kelapa ke seluruh dunia. Keunggulan kompetitif ini terus ke tingkat yang lebih tinggi sehingga PT. Putra 
Karangetang dapat memberikan kualitas yang lebih baik dan menghasilkan lebih banyak produk yang lebih baik. Jumlah karyawan di perusahaan ini 250 orang, terbagi atas: Kepala (1 orang), Operasional (3 orang), Bagian Administrasi Keuangan (2 orang), Bagian Produksi (50 orang), Bagian Personalia (1 orang), Bagian Marketing (1 orang), Bagian Persiapan (7 orang), Bagian Mesin (6 orang), Bagian Finishing (8 orang), Bagian Mekanik (6 orang), Bagian Gudang (4 orang ).

\section{Karakteristik Responden}

\section{Jenis Kelamin Responden}

Dalam mengkonsumsi suatu produk, maka jenis kelamin berpengaruh pada semua konsumen baik laki-laki maupun perempuan dalam melakukan kegiatan untuk memakai produk untuk memenuhi kebutuhan yang ada. Tabel 1 menunjukkan jenis kelamin pada PT. Putra Karangetang Minahasa Selatan.

Tabel 1. Jumlah Responden Menurut Jenis Kelamin (Pelanggan)

\begin{tabular}{llcc}
\hline No. & $\begin{array}{l}\text { Jenis } \\
\text { Kelamin }\end{array}$ & $\begin{array}{c}\text { Jumlah } \\
\text { (Orang) }\end{array}$ & $\begin{array}{c}\text { Presentase } \\
(\%)\end{array}$ \\
\hline 1 & Laki-laki & 19 & 63,33 \\
2 & Perempuan & 11 & 36,67 \\
\hline & Jumlah & 30 & 100
\end{tabular}

Sumber: Data Primer, tahun 2017

Tabel 1 menunjukkan jumlah responden yang menggunakan produk di PT. Putra Karangetang Minahasa Selatan berdasarkan jenis kelamin. Sebagian besar yang menggunakan produk perusahaan berjenis kelamin laki-laki dengan jumlah 22 orang $(63,33 \%)$, sedangkan perempuan sebanyak 8 orang $(36,67 \%)$ dari total seluruh responden.

\section{Umur Responden}

Umur mempengaruhi kemampuan seseorang dalam melakukan aktivitas maupun konsep berpikir khususnya dalam mengkonsumsi suatu produk. Karyawan yang memiliki umur lebih muda tentunya mempunyai selera yang berbeda dengan konsumen yang berumur dewasa. Berikut komposisi umur responden dalam peneliti ini.
Tabel 2. Jumlah Responden Berdasarkan Tingkat Umur

\begin{tabular}{clcc}
\hline No. & $\begin{array}{l}\text { Umur } \\
\text { Responden } \\
\text { (Tahun) }\end{array}$ & $\begin{array}{c}\text { Jumlah } \\
\text { (Orang) }\end{array}$ & $\begin{array}{c}\text { Presentase } \\
(\%)\end{array}$ \\
\hline 1 & $\leq 20$ & - & - \\
2 & $21-30$ & 17 & 56,67 \\
3 & $31-40$ & 10 & 33,33 \\
4 & $41-50$ & 3 & 10,00 \\
5 & $\geq 50$ & - & - \\
\hline & Jumlah & 30 & 100 \\
\hline
\end{tabular}

Sumber: Data Primer, tahun 2017

Tabel 2 menunjukkan bahwa jumlah responden terbanyak berada pada interval umur 21-30 tahun yaitu sebanyak 17 orang $(56,76 \%)$. Sedangkan jumlah konsumen terendah berada pada interval umur 41-50 tahun yaitu 3 orang $(10 \%)$.

\section{Tingkat Pendidikan}

Tingkah laku seseorang sangat dipengaruhi oleh pendidikan yang telah dicapai. Seorang karyawan yang memiliki pendidikan yang tinggi cenderung akan memilih suatu produk yang berkualitas. Begitu juga dalam mengambil keputusan untuk memilih alternatif pilihan yang dipilih. Berikut ini Tabel 3 yang menunjukkan jumlah responden berdasarkan tingkat pendidikan.

Tabel 3. Jumlah Responden Menurut Tingkat

\begin{tabular}{llcc}
\multicolumn{4}{c}{ Pendidikan } \\
\hline No. & Tingkat & $\begin{array}{c}\text { Jumlah } \\
\text { (orang) }\end{array}$ & $\begin{array}{c}\text { Persentase } \\
(\%)\end{array}$ \\
& Pendidikan & 1 & 3,33 \\
2 & SMP & 29 & 96,67 \\
\hline & SMA & 30 & 100 \\
\hline
\end{tabular}

Sumber: Data Primer, tahun 2017

Tabel 3 menunjukkan bahwa tingkat pendidikan responden yang terbanyak yaitu pada tingkat SMA dimana terdapat 29 orang karyawan (96,67\%), sedangkan tingkat pendidikan responden yang paling sedikit yaitu SMP 1 orang $(3,33 \%)$.

\section{Pekerjaan Responden}

Jenis pekerjaan apapun bisa mempengaruhi cara berpikir seseorang dalam memilih produk yang ada di PT. Putra Karangetang Minahasa Selatan. Pekerjaan seseorang menggambarkan barang yang diproduksi memiliki kualitas yang baik untuk dipakai pada saat sekarang. Berikut ini Tabel 4 
yang menunjukkan jumlah responden berdasarkan jenis pekerjaan, semuanya bekerja sebagai karyawan swasta.

Tabel 4. Jumlah Responden Menurut Jenis Pekerjaan

\begin{tabular}{llcc}
\hline No. & $\begin{array}{l}\text { Jenis } \\
\text { Pekerjaan }\end{array}$ & $\begin{array}{c}\text { Jumlah } \\
(\text { Orang) }\end{array}$ & $\begin{array}{c}\text { Presentase } \\
(\%)\end{array}$ \\
\hline 1 & Swasta & 30 & 100 \\
2 & Wiraswasta & - & - \\
\hline & Jumlah & 30 & 100 \\
\hline
\end{tabular}

Sumber: Data Primer, tahun 2017

\section{Jabatan Perusahaan}

Karakteristik responden berdasarkan jabatan atau bagian-bagian tugas pekerjaan di PT. Putra Karangetang Minahasa Selatan. Berikut ini tabel yang menunjukkan jumlah responden.

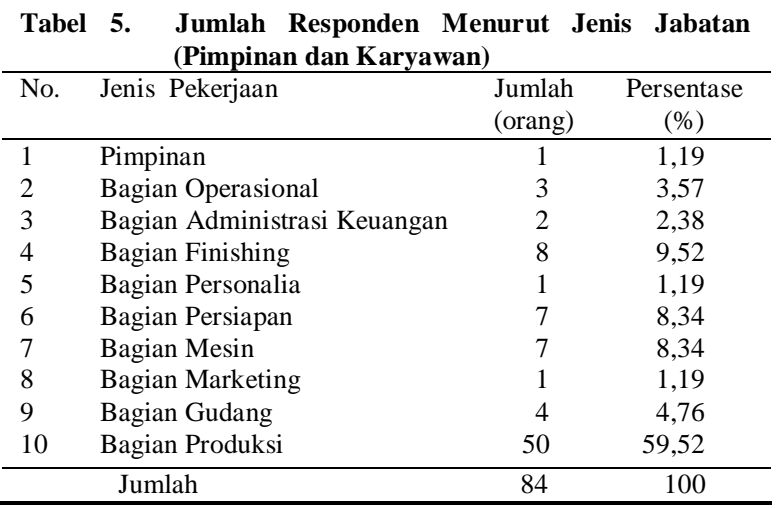

Sumber: Data Primer, tahun 2017

Dalam penelitian ini terdapat 10 kategori jenis pekerjaan atau bagian tugas dalam bagian persiapan dan bagian produksi masing-masing terdapat 50 orang responden $(166,6)$. Sedangkan jenis pekerjaan yang paling sedikit yaitu dalam bagian gudang dan bagian produksi masing-masing terdapat satu orang dari keseluruhan jumlah responden.

\section{Keunggulan Kompetitif}

Keunggulan kompetitif merupakan perusahaan yang bersaing dalam suatu lingkungan industri mempunyai keinginan untuk dapat lebih unggul dibandingkan pesaingnya. Keunggulan kompetitif perusahaan berusaha untuk memenangkan persaingan dengan cara menerapkan strategi yang bersaing tepat sehingga dapat mewujudkan tujuan-tujuan sesuai dengan apa yang diharapkan.
Pengukuran Keunggulan Kompetitif dalam penelitian ini berdasarkan 3 komponen yang penting, yaitu Strategi Biaya Rendah, Strategi Pembedaan Produk, dan Strategi Fokus.

\section{Strategi Biaya Rendah}

Strategi biaya rendah merupakan upaya perusahaan untuk menekankan upaya memproduksi produk standar dengan biaya yang sangat rendah. Perusahan haruslah menekankan visinya untuk berorientasi pada karyawan, terutama dalam kegiatan kebutuhan dan keinginan para pelanggannya. PT. Putra Karangetang Minahasa Selatan, berupaya untuk merancang pelayanan yang terbaik bagi pelanggannya, memiliki beberapa strategi yang dapat digunakan untuk meningkatkan kepuasan konsumen. Indikator-indikator terdiri dari: perusahaan punya produk yang dijual lebih rendah dari pesaing, perusahaan berupaya mendapatkan bahan baku yang murah, pasar produk yang besar dan luas, memanfaatkan sumber daya secara optimal, mendapatkan sumber pembiayaan dengan tingkat bunga yang rendah, pengendalian persediaan yang ketat.

\section{Harga Jual}

Harga jual adalah sauatu kesepakatan yang telah disepakati antara produsen dan konsumen. Harga jual pada PT. Putra Karangetang di Minahasa Selatan merupakan harga yang menjadi capaian atau kesepakatan antara pihak perusahaan dengan para konsumen, sehingga menjadikan salah satu kekuatan bagi pihak perusahaan untuk tetap mempertahankan keberlangsungan perusahaan serta menjaga kesetiaan dari pihak pembeli yang menjadi konsumen setia. Pernyataan tentang harga jual sebagai bagian dari strategi perusahaan untuk mendapatkan posisi keuntungan kompetesi perusahaan dapat dilihat pada Tabel 6 .

\begin{tabular}{lcccc}
\multicolumn{6}{c}{ Tabel 6. Produk yang Dijual Lebih Rendah dari Pesaing } \\
\hline $\begin{array}{l}\text { Alternatif } \\
\text { Jawaban }\end{array}$ & $\begin{array}{c}\text { Alternatif } \\
\text { Skor }\end{array}$ & $\begin{array}{c}\text { Jumlah } \\
\text { (Orang) }\end{array}$ & $\begin{array}{c}\text { Persentase } \\
\%\end{array}$ & $\begin{array}{c}\text { Total } \\
\text { Skor }\end{array}$ \\
\hline Sangat Setuju & 5 & 6 & 20,00 & 30 \\
Setuju & 4 & 5 & 16,67 & 20 \\
Netral & 3 & - & - & - \\
Tidak Setuju & 2 & 15 & 50,00 & 30 \\
Sangat tidak & 1 & 4 & 13,33 & 4 \\
setuju & & & & \\
\hline \multicolumn{5}{l}{ Total } \\
Sumber: Data Primer, tahun 2017
\end{tabular}


Tabel 6 menunjukkan bahwa terdapat 15 orang $(50 \%)$ berpendapat bahwa tidak setuju dengan pernyataan bahwa produk yang dijual lebih rendah dari pesaing. Terdapat 6 orang $(20 \%)$ sangat setuju dengan pernyataan tersebut, 5 orang $(16,6 \%)$ setuju dengan pernyataan tersebut. dan 4 orang $(13,3 \%)$ tidak setuju dengan pernyataan tersebut. Total skor yang diperoleh dari 30 responden pada indikator pertanyaan no 1 ini adalah 57, sehingga rata-rata dukungan sikap konsumen terletak pada daerah tidak setuju. Angka indeks persepsi konsumen mengenai perusahaan punya perhatian terhadap pelanggan yaitu: $84 / 150 \times 100$ $=56 \%$ sehingga interpretasi nilainya tergolong netral. Karena produk yang dijual belum tentu lebih rendah dari pesaing disebabkan untuk pelanggan yang tetap berlaku harga jual normal meskipun harga bahan baku mengalami kenaikan, sedangkan untuk pelanggan yang tidak tetap akan mengalami kenaikaan harga jual jika harga bahan baku naik.

\section{Harga Bahan Baku}

Perusahaan berusaha mandapatkan bahan baku yang murah dibandingkan dengan pesaing dimana harga bahan baku berhubungan secara langsung maupun tidak langsung terhadap proses prodksi dan akhirnya mempengaruhi harga jual produk. Tabel 7 berikut, tanggapan manajemen perusahaan terhadap pernyataan bahwa penentuan harga bahan baku menjadi bagian strategi perusahaan untuk mendapatkan keuntungan kompetitif.

Tabel 7. Harga Bahan Baku

\begin{tabular}{lcccc}
\hline $\begin{array}{l}\text { Alternatif } \\
\text { Jawaban }\end{array}$ & $\begin{array}{c}\text { Alternatif } \\
\text { Skor }\end{array}$ & $\begin{array}{c}\text { Jumlah } \\
\text { (Orang) }\end{array}$ & $\begin{array}{c}\text { Persentase } \\
\%\end{array}$ & $\begin{array}{c}\text { Total } \\
\text { Skor }\end{array}$ \\
\hline Sangat Setuju & 5 & - & - & - \\
Setuju & 4 & - & - & - \\
Netral & 3 & - & - & - \\
Tidak Setuju & 2 & 24 & 80 & 48 \\
Sangat tidak & 1 & 6 & 20 & 6 \\
setuju & & & & \\
\hline Total & & 30 & 100 & 54 \\
\hline
\end{tabular}

Sumber: Data Primer, tahun 2017

Berdasarkan Tabel 7 dapat dijelaskan bahwa hasil penelitian ini menunjukan 24 orang (80\%) responden berpendapat bahwa tidak setuju dengan pernyataan berupaya mendapatkan bahan baku murah. Terdapat 6 orang (20\%) sangat tidak setuju dengan pernyataan diatas. Total skor yang diperoleh dari 30 responden pada indikator pernyataan no 2 ini adalah 126, sehingga rata-rata sikap konsumen terletak pada daerah tidak setuju. Angka indeks persepsi karyawan mengenai bahan baku murah yaitu: 54/150x100 $=36 \%$ sehingga interpretasi nilainya tergolong tidak setuju. Berdasarkan hasil ini menunjukan bahwa tidak selamanya perusahaan mendapatkan bahan baku yang murah dibandingkan dengan pesaing, disebabkan bahan baku tidak hanya didapatkan dalam wilayah minahasa selatan akan tetapi bahan baku juga diambil dari luar wilayah minahasa selatan.

\section{Jangkauan Pasar}

Unsur penting dalam bisnis adalah suatu pasar produk yang besar dan luas untuk menanggapi apa yang di harapkan perusahan. Unsur seperti ini adalah salah satu cara yang terbaik dengan tujuan agar hubungan bisa membuat perusahan merasa dihargai dalam pengembangan produk yang baik. Berikut ini merupakan tanggapan pimpinan yang menyebutkan bahwa PT. Putra Karangetang Minahasa Selatan dapat dilihat pada Tabel 8.

\begin{tabular}{lcccc}
\multicolumn{6}{l}{ Tabel 8. Jangkauan pasar yang besar dan luas } \\
\hline $\begin{array}{l}\text { Alternatif } \\
\text { Jawaban }\end{array}$ & $\begin{array}{c}\text { Alternatif } \\
\text { Skor }\end{array}$ & $\begin{array}{c}\text { Jumlah } \\
\text { (Orang) }\end{array}$ & $\begin{array}{c}\text { Persentase } \\
\%\end{array}$ & $\begin{array}{c}\text { Total } \\
\text { Skor }\end{array}$ \\
\hline Sangat Setuju & 5 & - & - & - \\
Setuju & 4 & 23 & 76,6 & 92 \\
Netral & 3 & 7 & 23,3 & 21 \\
Tidak Setuju & 2 & - & - & - \\
Sangat tidak & 1 & - & - & - \\
setuju & & & & \\
\hline Total & & 30 & 100 & 113 \\
\hline Sumber: Data Primer, tahun 2017
\end{tabular}

Hasil penelitian ini menunjukkan bahwa 23 orang $(76,6 \%)$ responden berpendapat bahwa setuju dengan pernyataan tentang pasar produk yang besar dan luas. Terdapat 7 orang $(23,3 \%)$ Netral dengan pernyataan tersebut. Total skor yang diperoleh dari 30 responden pada indikator pertanyaan no 3 ini adalah 113/150 x $100=75,3 \%$ sehingga interpretasi nilainya tergolong setuju. Karena perusahan selalu melakukan dan mmemasarkan produk secara luas tidak hanya di dalam Sulawesi utara tetapi sampai ke luar daerah bahkan ke luar negeri. 


\section{Pemanfaatan sumber daya}

Sumber daya adalah adanya suatu nilai potensi yang dimiliki oleh suatu materi atau unsur tertentu dalam kehidupan PT. Putra Karangetang dalam memaksimalkan keuntungan dan meminimalkan resiko kerugian. Hal ini penting untuk mengembangkan perusahaan dalam pelayanan yang diberikan. Berikut ini tanggapan yang diberikan PT.Putara Karangetang dapat dilihat pada Tabel 9.

\begin{tabular}{lcccc}
\multicolumn{6}{c}{ Tabel 9. Memanfaatkan Sumber Daya Optimal } \\
\hline $\begin{array}{l}\text { Alternatif } \\
\text { Jawaban }\end{array}$ & $\begin{array}{c}\text { Alternatif } \\
\text { Skor }\end{array}$ & $\begin{array}{c}\text { Jumlah } \\
\text { (Orang) }\end{array}$ & $\begin{array}{c}\text { Persentase } \\
\%\end{array}$ & $\begin{array}{c}\text { Total } \\
\text { Skor }\end{array}$ \\
\hline Sangat Setuju & 5 & - & - & - \\
Setuju & 4 & 12 & 40 & 48 \\
Netral & 3 & 18 & 60 & 54 \\
Tidak Setuju & 2 & - & - & - \\
Sangat tidak & 1 & - & - & - \\
setuju & & & & \\
\hline Total & \multicolumn{5}{c}{100} & 102 \\
\hline
\end{tabular}

Sumber: Data Primer, tahun 2017

Hasil penelitian diatas menunjukkan bahwa 18 orang $(80 \%)$ berpendapat bahwa netral dalam pertanyaan no 4 tentang perusahan punya perhatian terhadap karyawan, terdapat 12 orang $(60 \%)$ setuju dengan pernyataan tersebut. Angka indeks persepsi konsumen mengenai perusahaan punya perhatian pada karyawan yaitu: $102 / 150 \times 100=68 \%$ sehingga interpretasi nilainya tergolong setuju. Berdasarkan hasil perusahaan selalu memberdayakan sumber daya yang ada di perusahaan dalam memaksimalkan keuntungan dan meminimalkan resiko kerugian.

\section{Sumber Pembiayaan}

Setiap perusahaan membutuhkan dana untuk tetap beroperasi, untuk memenuhi kebutuhan akan pengeluaran jangka pendek maupun panjang. Perushaan untuk mencapai tujuan untuk membantu meningkatkan nilai perusahaan. Berikut ini sumber pembiayaan dari PT.Putra Karangetang, dapat dilihat dari Tabel 10.

$\underline{\text { Tabel 10. Sumber pembiayaan }}$

\begin{tabular}{lcccc}
\hline $\begin{array}{l}\text { Alternatif } \\
\text { Jawaban }\end{array}$ & $\begin{array}{c}\text { Alternatif } \\
\text { Skor }\end{array}$ & $\begin{array}{c}\text { Jumlah } \\
\text { (Orang) }\end{array}$ & $\begin{array}{c}\text { Persentase } \\
\%\end{array}$ & $\begin{array}{c}\text { Total } \\
\text { Skor }\end{array}$ \\
\hline Sangat Setuju & 5 & - & - & - \\
Setuju & 4 & 2 & 6,6 & 8 \\
Netral & 3 & - & - & - \\
Tidak Setuju & 2 & 26 & 86,6 & 52 \\
Sangat tidak & 1 & 2 & 6.6 & 10 \\
setuju & & & & \\
\hline Total & & 30 & & \\
\hline Sumber: Data Primer tahun 2017 & & &
\end{tabular}

Hasil penelitian ini menunjukkan bahwa 26 orang $(86,6 \%)$ berpendapat bahwa tidak setuju dengan pernyataan no 5 tentang selalu menanggapi dengan cepat mendapatkan sumber pembiayaan dengan tingkkat bunga rendah. 2 orang $(6 \%)$ setuju dengan pernyataan tersebut, terdapat 2 Orang (6\%) sangat tidak setuju. Sehingga rata-rata dukungan sikap konsumen terletak pada daerah tidak setuju. Angka indeks persepsi konsumen mengenai menanggapi dengan cepat keinginan pelanggan yaitu: $70 / 150 \times 100=46,6 \%$ sehingga interpretasi nilainya tergolong setuju. Perusahaan berupaya mencari sumber-sumber pembiayaan dengan tingkat bunga yang rendah untuk memenuhi kebutuhan dana perusahaan baik pengeluaran jangka pendek maupun jangka panjang.

\section{Pengendalian persediaan}

Persediaan merupakan bagian utama perusahaan khususnya perusahaan dagang seringkali melibatkan modal kerja yang besar. Dalam pendekatan itu adalah satu cara perusahaan akan menghadapi resiko dimana pada suatu waktu tidak dapat memenuhi keinginan dari para pelanggannya. Berikut merupakan tanggapan karyawan dan pimpinan terhadap pengendalian persediaan yang menyebutkan bahwa PT. Putra Karangetang Minahasa Selatan menanggapi dengan cepat keinginan kariawan dan dapat dilihat pada Tabel 11.

\begin{tabular}{lcccc}
\multicolumn{6}{l}{ Tabel 11. Pengendalian Persediaan } \\
\hline Alternatif & $\begin{array}{c}\text { Alternatif } \\
\text { Skor }\end{array}$ & $\begin{array}{c}\text { Jumlah } \\
\text { (Orang) }\end{array}$ & $\begin{array}{c}\text { Persentase } \\
\%\end{array}$ & $\begin{array}{c}\text { Total } \\
\text { Skor }\end{array}$ \\
Jawaban & 5 & 2 & 6,6 & 10 \\
\hline Sangat Setuju & 4 & 28 & 93,3 & 112 \\
Setuju & 3 & - & - & - \\
Netral & 2 & - & - & - \\
Tidak Setuju & 1 & - & - & - \\
Sangat tidak & 100 & 122 \\
setuju & & 30 & 100 & \\
\hline Total & & & &
\end{tabular}

Hasil penelitian ini menunjukkan bahwa 28 orang $(93,3 \%)$ berpendapat bahwa setuju dengan pernyataan tentang pengendalian persediaan yang ketat. terdapat 2 orang $(6,6 \%)$ sangat setuju dengan pernyataan tersebut. Total skor yang diperoleh dari 30 responden pada indikator pernyataan no 6 ini adalah 122, sehingga rata-rata dukungan sikap konsumsi 
terletak pada daerah setuju. Angka indeks persepsi konsumen mengenai pengendalian persediaan yang ketat yaitu: 122/150x100 = $81,3 \%$ sehingga interpretasi nilainya tergolong setuju. Perusahaan mampu menerapkan pengendalian persediaan secara terarah sehingga persediaan bahan baku di perusahaan tetap ada, meskipun dalam keadaan kesulitan bahan baku.

\section{Rekapitulasi Strategi Biaya Rendah}

Dalam melakukan strategi biaya rendah perusahaan melakukannya dengan aspek jangkauan pasar, pemanfaatan sumberdaya dan pengendalian persediaan tapi tidak dalam aspek harga jual, harga bahan baku dan sumber pembiayaan.

\begin{tabular}{|c|c|c|c|c|}
\hline No. & Pernyataan & $\begin{array}{l}\text { Total } \\
\text { Skor }\end{array}$ & $\begin{array}{c}\text { Indeks } \\
\text { Kepuasan } \\
\%\end{array}$ & Interpretasi \\
\hline 1 & Harga Jual & 84 & $56 \%$ & Netral \\
\hline 2 & Harga Bahan Baku & 54 & $36 \%$ & Tidak Setuju \\
\hline 3 & Jangkauan Pasar & 113 & $75,3 \%$ & Setuju \\
\hline 4 & $\begin{array}{l}\text { Memanfaatkan sumber } \\
\text { daya }\end{array}$ & 102 & $68 \%$ & Setuju \\
\hline 5 & $\begin{array}{l}\text { Mendapatkan sumber } \\
\text { pembiayaan }\end{array}$ & 70 & $46,6 \%$ & Netral \\
\hline 6 & Pengendalian persediaan & 122 & $81,3 \%$ & $\begin{array}{l}\text { Sangat } \\
\text { Setuju }\end{array}$ \\
\hline
\end{tabular}

Sumber: Data Primer, tahun 2017

Tabel 12 menunjukkan bahwa terdapat 6 indikator strategi Biaya rendah terhadap sikap dimana indeks kepuasan tertinggi ada di pernyataan no 6 sebanyak $81,3 \%$ sedangkan indeks kepuasan terendah $36 \%$ terdapat pada pernyataan no 2 .

\section{Strategi Pembedaan Produk}

Semua perusahaan mencari beberapa jenis keunggulan kompetitif yang dapat membedakan produk mereka dan produk lainnya. Dapat disimpulkan bahwa segala sesuatu yang unik dan berbeda terhadap pelayanan, sehingga mereka lebih mudah mengenali dan mengingat produk tersebut. Hal ini berarti semua karyawan atau pimpinan di PT. Putra Karangetang Minahasa Selatan selalu berusaha melaksanakan setiap pekerjaannya. Terdapat 5 pernyataan yang diberikan dan telah dijawab oleh responden yaitu strategi pembedaan produk yang baik.

\section{Kelebihan dan Kekurangan Produk-Produk Pesaing}

Mempelajari secara kontinu kelebihan dan kekurangan produk pesaing sebagai perbedaan antara kenyataan dan harapan dari karyawan terhadap pelayanan yang mereka terima. Dapat disimpulkan bahwa kelebihan dari produk pesaing yaitu bagimana perusahaan selalu melihat jika ada barang yang cacat agar produk bisa berkualitas dan bisa memberikan pemenuhan keinginan dan kebutuhan konsumen dilihat dari tingkat keunggulan dan kualitas produk. Kekurangan dari produk tepung kelapa tidak di pasarkan di Sulawesi Utara hanya di ekspor ke luar negeri. Berikut tanggapan dari karyawan kelebihan dan kekurangan produk pada PT. Putra Karangetang Minahasa Selatan mengenai kelebihan dan kekurangan produk-produk pesaing.

\begin{tabular}{|c|c|c|c|c|}
\hline $\begin{array}{l}\text { Alternatif } \\
\text { Jawaban }\end{array}$ & $\begin{array}{l}\text { Alternatif } \\
\text { Skor }\end{array}$ & $\begin{array}{l}\text { Jumlah } \\
\text { (Orang) }\end{array}$ & $\begin{array}{c}\text { Persentase } \\
\%\end{array}$ & $\begin{array}{l}\text { Total } \\
\text { Skor }\end{array}$ \\
\hline Sangat Setuju & 5 & - & - & - \\
\hline Setuju & 4 & 15 & 50 & 60 \\
\hline Netral & 3 & 14 & 46,6 & 42 \\
\hline Tidak Setuju & 2 & 1 & 3,3 & 2 \\
\hline $\begin{array}{l}\text { Sangat tidak } \\
\text { setuju }\end{array}$ & 1 & - & - & - \\
\hline Total & & 30 & 100 & 104 \\
\hline
\end{tabular}

Sumber: Data Primer, tahun 2017

Hasil penelitian ini menunjukkan bahwa 15 orang $(50 \%)$ responden berpendapat bahwa setuju dengan penyataan no 1 tentang mempelajari secara kontinu dan kekurangan produk-produk pesaing. Terdapat 14 orang $(46,6 \%)$ netral dengan pernyataan tersebut, terdapat 1 orang $(3,3 \%)$ sangat tidak setuju dengan pernyataan diatas. Total skor yang diperoleh dari 30 responden pada indikataor ini adalah 104, sehingga rata-rata dukungan sikap konsumen terletak pada daerah setuju. Angka indeks persepsi karyawan mengenai pelayanan yang baik bagi pelanggannya yaitu: 104/150x100 $=69,3 \%$ sehingga interpretasi nilainya tergolong setuju. Perusahaan selalu mampu melakukan evaluasi kelebihan dan kekurangan dari produk-produk pesaing seperti melihat dari kualitas produk pesaing dari tingkat kemasan, warna, dan tekstur. 


\section{Perbedaan Produk}

Unsur penting dalam bisnis produk yang dihasilkan berbeda dengan pesaing. Dalam pendektan seperti itu adalah salah satu cara yang terbaik dengan tujuan supaya membuat karyawan dan pimpinan dihargai, mengidentifikasi dengan cepat keinginan dari konsumen untuk pengembangan produk yang dihasilkan. Berikut merupakan tanggapan konsumen terhadap perbedaan produk pada PT. Putra Karangetang Minahasa Selatan, dapat dilihat pada Tabel 14.

\begin{tabular}{lcccc}
\multicolumn{6}{c}{ Tabel 14. Produk yang Dihasilkan Berbeda Dengan Pesaing } \\
\hline $\begin{array}{l}\text { Alternatif } \\
\text { Jawaban }\end{array}$ & $\begin{array}{c}\text { Alternatif } \\
\text { Skor }\end{array}$ & $\begin{array}{c}\text { Jumlah } \\
\text { (Orang) }\end{array}$ & $\begin{array}{c}\text { Persentase } \\
\%\end{array}$ & $\begin{array}{c}\text { Total } \\
\text { Skor }\end{array}$ \\
\hline Sangat Setuju & 5 & - & - & - \\
Setuju & 4 & 1 & 3,3 & 4 \\
Netral & 3 & 29 & 96,6 & 87 \\
Tidak Setuju & 2 & - & - & - \\
Sangat tidak & 1 & - & - & - \\
setuju & & & & \\
\hline Total & \multicolumn{5}{c}{30} & 100 & 91 \\
\hline
\end{tabular}

Sumber: Data Primer, tahun 2017

Hasil penelitian diatas menunjukkan bahwa 29 orang $(96,6 \%)$ berpendapat bahwa netral dengan pernyataan no 2 tentang selalu menanggapi dengan cepat keinginan karyawan. terdapat 1 orang $(3,3 \%)$ setuju dengan pernyataan tersebut. Total skor yang diperoleh dari 30 responden ini adalah 91, sehingga ratarata dukungan sikap karyawan dan pimpinan terletak pada daerah netral. Angka indeks persepsi mengenai produk yang dihasilkan berbeda dengan pesaing yaitu: 91/150x100 = 60,6 , sehingga interpretasi nilainya tergolong netral. Perusahaan mampu menghasilkan produk-produk yang tidak jauh berbeda dari pesaing meskipun ada beberapa perbedaan dari produk yang akan dihasilkan dari perusahaan.

\section{Harga Jual Produk}

Harga yang ditetapkan suatu produk baru harus dapat memberikan pengaruh yang baik bagi pertumbuhan pasar, selain itu untuk mencegah timbulnya pesaing. Dapat disimpulkan bahwa harga produk terbaru yaitu bagaiman perusahaan selalu mengontrol hasil produk bisa berkualitas dan bisa memberikan pemenuhan kebutuhan konsumen. Berikut ini tanggapan dari kayawan dan pimpinan PT. Putra Karangetang Minahasa Selatan mengenai harga produk yang terbaru.

\begin{tabular}{lcccc}
\multicolumn{6}{l}{ Tabel 15. Harga Produk yang Terbaru } \\
\hline $\begin{array}{l}\text { Alternatif } \\
\text { Jawaban }\end{array}$ & $\begin{array}{c}\text { Alternatif } \\
\text { Skor }\end{array}$ & $\begin{array}{c}\text { Jumlah } \\
\text { (Orang) }\end{array}$ & $\begin{array}{c}\text { Persentase } \\
\%\end{array}$ & $\begin{array}{c}\text { Total } \\
\text { Skor }\end{array}$ \\
\hline Sangat Setuju & 5 & - & - & - \\
Setuju & 4 & - & - & - \\
Netral & 3 & 30 & 100 & 90 \\
Tidak Setuju & 2 & - & - & - \\
Sangat tidak & 1 & - & - & - \\
setuju & & & & \\
\hline Total & \multicolumn{7}{l}{} \\
\hline
\end{tabular}

Sumber: Data Primer, tahun 2017

Hasil penelitian ini menunjukkan bahwa 30 orang $(100 \%)$ responden berpendapat bahwa netral dengan pernyataan no 3 tentang harga produk yang baru tersebut. Total skor yang diperoleh dari 30 responden pada indikator pernyataan no 3 ini adalah 90, sehingga ratarata dukungan sikap karyawan dan pimpinan terletak pada daerah netral. Angka indeks persepsi mengenai peningkatan kualitas produk yaitu: $90 / 150 \times 100=60 \%$ sehingga interpretasi nilainya tergolong netral. Karena harga jual produk yang terbaru berlaku hanya untuk pelanggan baru sedangkan pelanggan tetap akan berlaku harga tetap.

\section{Pemanfaatan Teknologi}

Dapat didefinisikkan perusahaan harus memberikan perhatian yang sama besarnya kepada para pesaing dengan diberikan kepada para pelanggan sasaran mereka. Setiap perusahaan yang memproduksi dan menjual produk dan jasa yang sama dengan kisaran harga yang sama kepada pelanggan yang sama. Berikut ini merupakkan tanggapan dari Pimpinan dan karyawan terhadap pemanfaatan teknologi pada PT. Putra Karangetang Minahasa Selatan, dapat dilihat pada Tabel 16.

Tabel 16. Pemanfaatan Teknologi yang Baru

\begin{tabular}{lcccc}
\hline $\begin{array}{l}\text { Alternatif } \\
\text { Jawaban }\end{array}$ & $\begin{array}{c}\text { Alternatif } \\
\text { Skor }\end{array}$ & $\begin{array}{c}\text { Jumlah } \\
\text { (Orang) }\end{array}$ & $\begin{array}{c}\text { Persentase } \\
\%\end{array}$ & $\begin{array}{c}\text { Total } \\
\text { Skor }\end{array}$ \\
\hline Sangat Setuju & 5 & - & - & - \\
Setuju & 4 & 28 & 93,3 & 112 \\
Netral & 3 & 2 & 6,6 & 6 \\
Tidak Setuju & 2 & - & - & - \\
Sangat tidak & 1 & - & - & - \\
setuju & & & & \\
\hline Total & 30 & 100 & 118 \\
\hline Sumber: Data Primer, tahun 2017 &
\end{tabular}

Hasil penelitian ini menunjukkan bahwa 28 orang $(93 \%)$ berpendapat bahwa setujun dengan pernyataan no 4 tentang penggunaan 
produkyang bersaing. terdapat 2 orang $(6,6 \%)$ netral dengan pernyataan tersebut. Total skor yang diperoleh dari 30 responden pada indikator ini adalah 118, sehingga rata-rata dukungan sikap konsumen terletak pada daerah setuju. Angka indeks mengenai penggunaan produk yang bersaing yaitu: $118 / 150 \times 100=78,6 \%$ sehingga interpretasi nilainya tergolong setuju. Perusahaan selalu mengikuti kemajuan teknologi dengan memanfaatkan teknologi yang baru untuk memproduksi serta menjual produk-produk yang dihasilkan perusahaan.

\section{Memiliki Pusat Research and Development}

Adanya perusahaan yang bertanggung jawab untuk segala aktivitas riset dan pengembangan di perusahaan tersebut. Research and Development biasanya bertanggung jawab mengelolah sejumlah dana tertentu yang telah dianggarkan perusahaan untuk riset dan pengembangan untuk meningkatkan kualitas produk yang dihasilkan perusahaan. Berikut ini tanggapan dari Pimpinan dan Karyawan PT. Putra Karangetang Minahasa Selatan mengenai Memiliki pusat research and development.

Tabel 17. Memiliki Pusat Research and Development

\begin{tabular}{lcccc}
\hline $\begin{array}{l}\text { Alternatif } \\
\text { Jawaban }\end{array}$ & $\begin{array}{c}\text { Alternatif } \\
\text { Skor }\end{array}$ & $\begin{array}{c}\text { Jumlah } \\
\text { (Orang) }\end{array}$ & $\begin{array}{c}\text { Persentase } \\
\%\end{array}$ & $\begin{array}{c}\text { Total } \\
\text { Skor }\end{array}$ \\
\hline Sangat Setuju & 5 & 2 & 6,6 & 10 \\
Setuju & 4 & 28 & 93,3 & 112 \\
Netral & 3 & - & - & - \\
Tidak Setuju & 2 & - & - & - \\
$\begin{array}{l}\text { Sangat tidak } \\
\text { setuju }\end{array}$ & 1 & - & - & - \\
& & & & \\
\hline Total & & 30 & 100 & 122 \\
\hline Sumber: Data Primer, tahun 2017 & & &
\end{tabular}

Hasil penelitian ini menunjukkan bahwa 28 orang $(93,3 \%)$ berpendapat bahwa setuju dengan pernyataan teresebut. terdapat 2 orang $(6,6 \%)$ responden berpendapat sangat setujudengan pernyataan diatas. Total skor yang diperoleh dari 30 responden pada indikator pernyataan no 5 ini adalah 112, sehingga rata-rata dukungan sikap Pimpinan dan Karyawan terletak pada daerah setuju. Angka indeks persepsi mengenai memiliki pusat Research and Development yaitu: $112 / 150 \times 100=81,3 \%$ sehingga interpretasi nilainya tergolong sangat setuju. Berdasarkan penelitian diatas menunjukkan perusahaan selalu mempertahankan konsumen agar tetap loyal dengan perusahaan seperti memberikan pelayanan yang terbaik dan tepat waktu.

\section{Tabel 18. Rekapitulasi Strategi Pembedaan Produk}

Dalam melakukan strategi pembedaan produk perusahaan melakukan dengan aspek kelebihan dan kekurangan produk pesaing, produk yang dihasilkan berbeda dengan pesaing, harga produk terbaru, memiliki pusat research and development.

\begin{tabular}{llccc}
\hline No. & Pernyataan & $\begin{array}{c}\text { Total } \\
\text { Skor }\end{array}$ & $\begin{array}{c}\text { Indeks } \\
\text { Kepuasan } \\
\%\end{array}$ & Interpretasi \\
\hline 1 & $\begin{array}{l}\text { Kelebihan dan } \\
\text { kekurangan produk }\end{array}$ & 104 & $69,3 \%$ & Setuju \\
2 & Perbedaan produk & 91 & $60,6 \%$ & Setuju \\
3 & Harga jual produk & 91 & $60 \%$ & Netral \\
4 & Pemanfaatana & 118 & $78,6 \%$ & Setuju \\
& teknologi & & & Sangat \\
5 & $\begin{array}{l}\text { Memilki pusat } \\
\text { Research and }\end{array}$ & 122 & $81,3 \%$ & Setuju \\
& Development & & & \\
\hline Sumber: Data Primer, tahun 2017 & & &
\end{tabular}

Tabel 18 menunjukkan bahwa terdapat 5 indikator Strategi Pembedaan Produk terhadap sikap dimana indeks kepuasan tertinggi ada 4 pernyataan sebanyak 81,3\%, sedangkan pernyataan ke 2 sebanyak 60,6.

\section{Strategi Fokus}

Dalam organisasi strategi fokus digunakan untuk membangun keunggulan bersaing dalam suatu segmen pasar yang lebih sempit. Hal ini berarti bahwa semua karyawan dan pimpinan di PT. Putra Karangetang Minahasa Selatan selalu berusaha memenuhi kebutuhan konsumen secara baik. Terdapat 3 pernyataan yang diberikan dan telah dijawab oleh responden yaitu berupaya untuk mempertahankan pasar/konsumen yang sudah ada dan memiliki konsep penentuan harga pasar (permintaan) dan mempertahankan kualitas produk yang dihasilkan. 


\section{Fokus pada Pasar}

Hal paling penting dalam mempertahankan konsumen adalah bagaimana supaya konsumen tetap loyal dengan suatu perusahaan dibandingkan dengan perusahaan lain,dalam semua situasi bisnis lebih mahal untuk mencari konsumen baru dibandingkan mempertahankan pasar/konsumen. Berikut ini tanggapan dari pimpinan dan karyawan PT. Putra Karangetang Minahasa Selatan mengenai berupaya untuk mempertahankan pasar/konsumen yang sudah ada.

Tabel 19. Fokus pada Pasar

\begin{tabular}{lcccc}
\hline $\begin{array}{l}\text { Alternatif } \\
\text { Jawaban }\end{array}$ & $\begin{array}{c}\text { Alternatif } \\
\text { Skor }\end{array}$ & $\begin{array}{c}\text { Jumlah } \\
\text { (Orang) }\end{array}$ & $\begin{array}{c}\text { Persentase } \\
\%\end{array}$ & $\begin{array}{c}\text { Total } \\
\text { Skor }\end{array}$ \\
\hline Sangat Setuju & 5 & 2 & 6,6 & 10 \\
Setuju & 4 & 28 & 93,3 & 112 \\
Netral & 3 & - & - & - \\
Tidak Setuju & 2 & - & - & - \\
Sangat tidak & 1 & - & - & - \\
setuju & & & & \\
\hline Total & & 30 & 100 & 122 \\
\hline Sumber: & & & &
\end{tabular}

Sumber: Data Primer, tahun 2017

Hasil penelitian diatas menunjukkan bahwa 28 orang $(93,3 \%)$ berpendapat bahwa setuju dengan pernyataan berupaya untuk mempertahankan pasar/konsumen yang ada. terdapat 2 orang $6,6 \%$ ) responden sangat setuju dengan pernyataan tersebut. Total skor yang diperoleh dari 30 responden pada indikator ini adalah 122, sehingga rata-rata dukungan karyawan dan pimpinan terletak dpada daerah setuju. Angka indeks persepsi mengenai berupaya untuk mempertahankan pasar/konsumen yang sudah ada yaitu: $122 / 150 \times 100=81,3 \%$ sehingga interpretasi nilainya tergolong setuju. Berdasarkan hasil penelitian perusahan menunjukkan pelayanan yang baik pada konsumen.

\section{Penentuan Harga Pasar}

Salah satu nilai utama yang diharapkan memiliki penentuan harga pasar (permintaan) untuk menetapkan tingkat harga tersebut biasanya dilakukan dengan mengadakan percobaan untuk menguji pasarnya, apakah menerima atau menolak hal ini disebabkan karena harga merupakan bagian dari penawaran suatu barang, seperti juga pada kemasan atau merk. Tanggapan dari pimpinan dan karyawan PT. Putra Karangetang Minahasa Selatan mengenai memiliki konsep penentuan harga pasar (permintaan) dapat dilihat dalam tabel berikut ini.

\begin{tabular}{lcccc}
\multicolumn{6}{l}{ Tabel 20. Fokus pada Pasar } \\
\hline Alternatif & $\begin{array}{c}\text { Alternatif } \\
\text { Skor }\end{array}$ & $\begin{array}{c}\text { Jumlah } \\
\text { (Orang) }\end{array}$ & $\begin{array}{c}\text { Persentase } \\
\%\end{array}$ & $\begin{array}{c}\text { Total } \\
\text { Skor }\end{array}$ \\
\hline Jawaban & 5 & 2 & 6,6 & 10 \\
Sangat Setuju & 4 & 28 & 93,3 & 112 \\
Setuju & 3 & - & - & - \\
Netral & 2 & - & - & - \\
Tidak Setuju & 1 & - & - & - \\
Sangat tidak & & & & \\
setuju & & 30 & 100 & 122 \\
\hline Total
\end{tabular}

Sumber: Data Primer, tahun 2017

Hasil penelitian diatas ini menunjukkan bahwa 28 orang $(93,3 \%)$ responden berpendapat bahwa setuju dengan pernyataan tentang PT. Putra Karangetang Minahasa Selatan. terdapat 2 orang $(6,6 \%)$ responden sangat setuju dengan pernyataan diatas. Total skor yang diperoleh dari 30 responden pada indikator pertanyaan no 13 ini adalah 122, sehingga rata-rata dukungan sikap karyawan dan pimpinan terletak pada daerah setuju. Angka indeks persepsi mengenai memiliki konsep penentuan harga pasar (permintaan) yaitu: $122 / 150 \times 100=81,3 \%$ sehingga interpretasi nilainya tergolong setuju. Ini menunjukkan bahwa perusahaan memiliki penetuan harga pasar (permintaan) yang biasanya dilakukan untuk menguji pasar untuk melhat apakah konsumen menerima atau menolak harga yang ditawarkan dari perusahaan.

\section{Kualitas Produk}

Dapat didefinisikan sebagai seberapa jauh dari pelanggan terhadap perbedaan antara kenyataan dan harapan dari yang mereka terima. Dapat disimpulkan bahwa peningkatan kualitas produk yaitu bagaimana perusahaan selalu mengontrol jika ada barang yang cacat agar hasil produk bisa berkualitas dan bisa berkualitas dan bisa memberikan pemenuhan kebutuhan dan keinginan konsumen dilihat dari tingkat keunggulan kualitas yang diharapkan. Berikut ini tanggapan dari pimpinan dan karyawan PT. Putra Karangetang Minahasa Selatan mengenai Mempertahankan kualitas produk yang dihasilkan. 
Tabel 21. Kualitas Produk

\begin{tabular}{lcccc}
\hline $\begin{array}{l}\text { Alternatif } \\
\text { Jawaban }\end{array}$ & $\begin{array}{c}\text { Alternatif } \\
\text { Skor }\end{array}$ & $\begin{array}{c}\text { Jumlah } \\
\text { (Orang) }\end{array}$ & $\begin{array}{c}\text { Persentase } \\
\%\end{array}$ & $\begin{array}{c}\text { Total } \\
\text { Skor }\end{array}$ \\
\hline Sangat Setuju & 5 & 10 & 33,3 & 50 \\
Setuju & 4 & 20 & 66,6 & 80 \\
Netral & 3 & - & - & - \\
Tidak Setuju & 2 & - & - & - \\
Sangat tidak & 1 & - & - & - \\
setuju & & & & \\
\hline Total & & 30 & 100 & 130 \\
\hline
\end{tabular}

Sumber: Data Primer, tahun 2017

Hasil penelitian ini menunjukkan bahwa 20 orang $(66,6 \%)$ berpendapat bahwa setuju dengan pernyataan tentang Mempertahankan kualitas produk yang dihasilkan. Terdapat 10 orang $(33,3 \%)$ responden setuju dengan pernyataan tersebut. Total skor yang diperoleh dari 30 responden pada indikator ini adalah 140 , sehingga rata-rata dukungan sikap pimpinan dan karyawan terletak pada daerah sangat setuju. Angka indeks persepsi mengenai mempertahankan kualitas produk yang dihasilkan yaitu: $130 / 150 \times 100=86,6 \%$ sehingga interpretasi nilainya tergolong sangat setuju. Berdasarkan hasil dari penelitian diatas menunjukkan bahwa perusahaan berupaya menghasilkan produk-produk yang berkualitas baik dari segi kemasan, tekstur, warna, keamanan produk serta jangka waktu penggunaan.

\section{Tabel 22. Rekapitulasi Fokus}

Dalam melakukan strategi focus perusahaan melakukan dengan aspek focus pada pasar, penentuan harga pasar, dan kualitas produk.

\begin{tabular}{llccc}
\hline No. & Pernyataan & $\begin{array}{c}\text { Total } \\
\text { Skor }\end{array}$ & $\begin{array}{c}\text { Indeks } \\
\text { Kepuasan } \\
\%\end{array}$ & Interpretasi \\
\hline 1 & $\begin{array}{l}\text { Berupaya focus pada } \\
\text { pasar }\end{array}$ & 122 & $81,3 \%$ & Setuju \\
2 & $\begin{array}{l}\text { Penentuan harga } \\
\text { pasar }\end{array}$ & 122 & $81,3 \%$ & Setuju \\
3 & Kualitas produk & 130 & $86,6 \%$ & $\begin{array}{c}\text { Sangat } \\
\text { setuju }\end{array}$ \\
\hline
\end{tabular}

Sumber: Data Primer, tahun 2017

Tabel 22 menunjukkan bahwa terdapat 3 indikator Strategi Fokus dimana terdapat sikap indeks kepuasan tertinggi 3 pernyataan yaitu pernyataan 1 sebanyak $86,6 \%$ setuju, Pernyataan 2 sebanyak $81,3 \%$ setuju, pernyataan 3 sebanyak 93,3\% sangat setuju.

Untuk mengetahui letak kepuasan pelanggan terdapat Staregi Biaya Rendah maka perlu dihitung jumlah keseluruhan skor pada setiap kriterium, dimana sesuai dengan hasil penelitian ini skor mencapai. Pada penelitian ini jumlah skor ideal (skor tertinggi) yaitu (tinggi) 2100 dan jumlah skor terendah yaitu 420 (rendah). Berdasarkan data yang dihimpun dari 14 Instrumen pernyataan yang diajukan kepada 30 responden maka diperoleh total 1515, dengan letak indeks ditentukan berdasarkan Skala Likert.

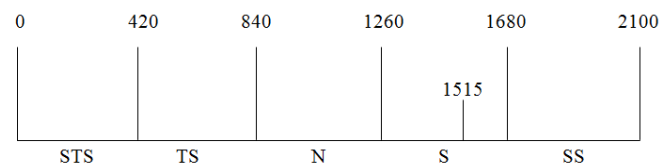

Berdasarkan skala diatas, dapat dilihat dari dapat dilihat bahwa kepuasan konsumen terhadap fokus pada pelanggan terletak pada daerah tidak setuju. Secara persentase, angka indeks, persepsi Strategi biaya rendah pada PT. Putra Karangetang Minahasa Selatan.

Tingkat Kepuasan Responden

$$
\begin{aligned}
& =\frac{\text { Jumlah Skor Hasil Pengumpulan Data }}{\text { Jumlah Skor Ideal (Tertinggi) }} \times 100 \% \\
& =\frac{\mathbf{1 5 1 5}}{\mathbf{2 1 0 0}} \times 100 \% \\
& =72,14 \%
\end{aligned}
$$

Dengan interpretasi nilai :

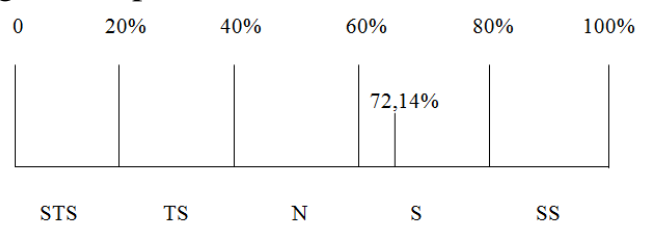

Berdasarkan hasil analisis menggunakkan Skala Likert, maka dapat diketahui bahwa angka indeks persepsi pimpinan dan karyawan Keunggulan Kompetitif Produk Tepung Kelapa di PT. Putra Karangetang Minahasa Selalatan berada pada titik $72,14 \%$ dan tergolong setuju. Setiap karyawan memiliki sikap, pengalaman yang berbeda dalam bekerja di PT. Putra Karangetang Minahasa Selatan. Dari hasil wawancara kepada karyawan dan pimpinan mereka mampu meberikan perhatian, pelayanan baik bagi konsumen. Hasil penelitian diperoleh bahwa secara keseluruhan persepsi Keunggulan Kompetitif adalah netral, yang artinya pimpinan dan karyawan di PT. Putra Karangetang Minahasa Selatan harus menerapkan secara benar Keunggulan Kompetitif agar supaya perusahaan bisa lebih berkembang dan produk yang dihasilkan bisa berkualitas. 


\section{KESIMPULAN DAN SARAN}

\section{Kesimpulan}

Dalam melakukan strategi biaya rendah perusahaan melakukan dalam aspek jangkauan pasar, pemanfaatan sumber daya dan pengendalian persediaan. Tapi tidak dalam harga jual, harga bahan baku dan sumber pembiayaan. Dalam melakukan strategi pembedaan produk perusahaan melakukan dalam aspek memiliki pusat research and development, kelebihan dan kekurangan produk, pembedaan produk dan pemanfaatan teknologi, tapi tidak dalam harga jual produk. Dalam melakukan strategi focus perusahaan melakukan dalam aspek focus pada pasar, penentuan harga pasar dan kualitas produk. Dari ketiga strategi ini perusahaan sudah menjalankan akan tetapi perusahaan perlu memperhatikan setiap aspek-aspek yang ada pada ketiga strategi ini untuk mencapai keunggulan kompetitif produk tepung kelapa pada PT. Putra Karangetang Minahasa Selatan.

\section{Saran}

Berdasarkan kesimpulan dari hasil penelitian, maka dapat disarankan, bahwa untuk meningkatkan kualitas produk yang dihasilkan oleh PT. Putra Karangetang Minahasa Selatan, harus memperhatikan keseluruhan indikatorindikator keunggulan kompetitif seperti strategi biaya rendah, strategi pembedaan produk, dan strategi fokus.

Selain itu kelemahan dari penelitian ini tidak ada perusahan pembanding sehingga penelitian ini hanya melihat sejauh mana keunggulan kompetitif produk tepung kelapa pada PT. Putra Karangtang Minahasa Selatan.

\section{DAFTAR PUSTAKA}

Aditya, Helmi., 2004. "Analisis Pengaruh Merek, Orientasi Strategik, dan Inovasi Terhadap Keunggulan Bersaing (Studi UKM Tanggulangin di Kota Sidoarjo)". Jurnal Sains Pemasaran Indonesia, Vol III, No 3 Program Magister Manajemen. Universitas Diponegor.
Agustine Ira. 2014. Pengaruh Comperative social Responsibility Terhadap Nilai Perusahaan.

Barney, Jay B, 2002. Gaining and Sustaining Competitive Advantage. Second Edition.

Brigham,Eugene dan Joel F Hauston, 2001. Manejemen Keuangan II. Jakarta Salemba Empat.

Ferdinand, A. 2003. Struktural equation modeling dalam Penelitian Manejemen, Badan Penerbit Universitas Dipenogoro.

Gibson, Ivancevich Donelly. 1996. Organisasi, Perilaku, Struktur, Poroses, Bina Rupa Aksara, Jakarta.

Hashemi, M. Habibi, A, Jahashahi, N, 2012, Determination of cyclamate in Artifical Sweeternes and Beverages using Headspace Single-drop Microextraction and gas Choromatography flame-inisation Detection, food cheministry.

Inc. Lei, David dan Scolum Jr, John W. 2002. Organization Designs to Renew Competitiv Advantage. Organizational Dynamics, Vol. 31, No.1, pp. 1-18.

Kotler, Amstrong. 2001. Prinsip-Prinsip Pemasaran, Edisi ke 8. Terjemahan Damos Sihombing, MBA, Jakarta Erlangga.

Lumpkin, Dess. 2003. Strategic Management: Creating Competitive Advantages. McGraw-Hill Companies, Inc.

Porter, Michael E. 1996. What is Strategy? Harvard Business Review, Vol 74 (6): 6178.

Rengkung, L. R. 2015. Keuntungan Kompetitif Organisasi dalam Persekptif Resources Based View (RBV). Jurnal ASE Vol.11 No. 2A.

Setiawan, 2006. Pria dan Andropouse, http://Bkkn go.id/Artikel Detail. 2013.

Sarason, Yolanda dan Tegarden, Linda F. 2003. The Erosion of the Competitive Advantage of Strategic Planning: A Configuration Theory and Resource Based View. Journal of Business and Management, Vol. 9, No1. 